\title{
Female autonomy and rural tourism in Tzibanzá, Cadereyta de Montes, Querétaro, Mexico
}

\author{
Ilithya Guevara Hernández
}

Faculty of Political Sciences, Universidad Autonoma de Queretaro, Mexico

Correspondence author email:ilithya.guevara@uaq.mx

\begin{tabular}{|l|l|l|l|l|}
\hline DOI: & Received: & Revised: & Accepted: & Published: \\
10.22437/ppd.v8i5.10497 & 17.09 .2020 & 24.12 .2020 & 25.12 .2020 & 31.12 .2020 \\
\hline
\end{tabular}

\begin{abstract}
One of the elements that are disrupted by development is gender roles. These changes are not always negative, and the objective is to identify whether the participation of women in the fishing cooperative and the tourism project of La Isla makes it possible to build autonomy. Ever since the 90s, the Tzibanzá village has been the target of a series of development projects that have included or excluded them in decision-making. However, every project impacted the organization and productive activities and their daily life. Results of an investigation still in progress are presented, which start from the qualitative approach combining quantitative information-gathering techniques: a questionnaire to cooperative members and not cooperative members; and qualitative: non-participant observation, qualitative interviews, and focus groups. The tourism production and project cooperative have operated for just over 20 years with relative success in income, job creation, and participation. Women have been incorporated not necessarily by their own decision, but in their husbands' absence due to migration or the position was inherited. However, participating in activities considered "masculine" leads them to reconsider their role in the community and family, enabling decision-making to previously had no access. Autonomy indeed needs social recognition to be exercised; however, we consider that joining actively and as protagonists in productive activities allows progress.
\end{abstract}

Keywords: Autonomy, Rural tourism, Gender, Women

JEL Classsification: I31, J16, R29

\section{INTRODUCTION}

The development processes that have marked the history of the rural environment in Mexico took place since the 90s in the last century; furthermore, those have included women to cover a gender quota to promote equality or with the idea of empowerment. The gender quota it's a measure that seeks to respond to the current gender imbalance in decision-making institutions, and it can be used to refer to the participation of women in development projects

Not in all cases have they been considered protagonists of the processes, and many of the proposals reinforce traditional gender roles that place them as mothers, caregivers, and homemakers. However, in the case of Tzibanzá, women have been participants in the changes, succeeding in repositioning themselves in the public space due to their inclusion in the sports and commercial fishing cooperative activities as tourism projects. 
Particularly regarding commercial fishing and decision-making that had been considered male activities linked to providers' role. The pages that follow come from an investigation that has not yet been concluded. It aims to identify whether women's participation in development programs and projects could be considered a female autonomy trigger, the changes perceived and found in private and public spaces.

\section{LITERATURE REVIEW}

It is important to understand the context and concept we used to analyze their reality, to understand the impact that development programs and projects have had on the lives of the people of Tzibanzá, specifically on women.

\section{Geospatial and sociodemographic context}

Tzibanzá, it's a rural community that politically is part of one of the nine delegations that make up Cadereyta de Montes' municipality in the state of Querétaro (Figure 1). This area has been marked by poverty and marginalization conditions, making it difficult for groups to reproduce, regardless of the federal and state governments' efforts.

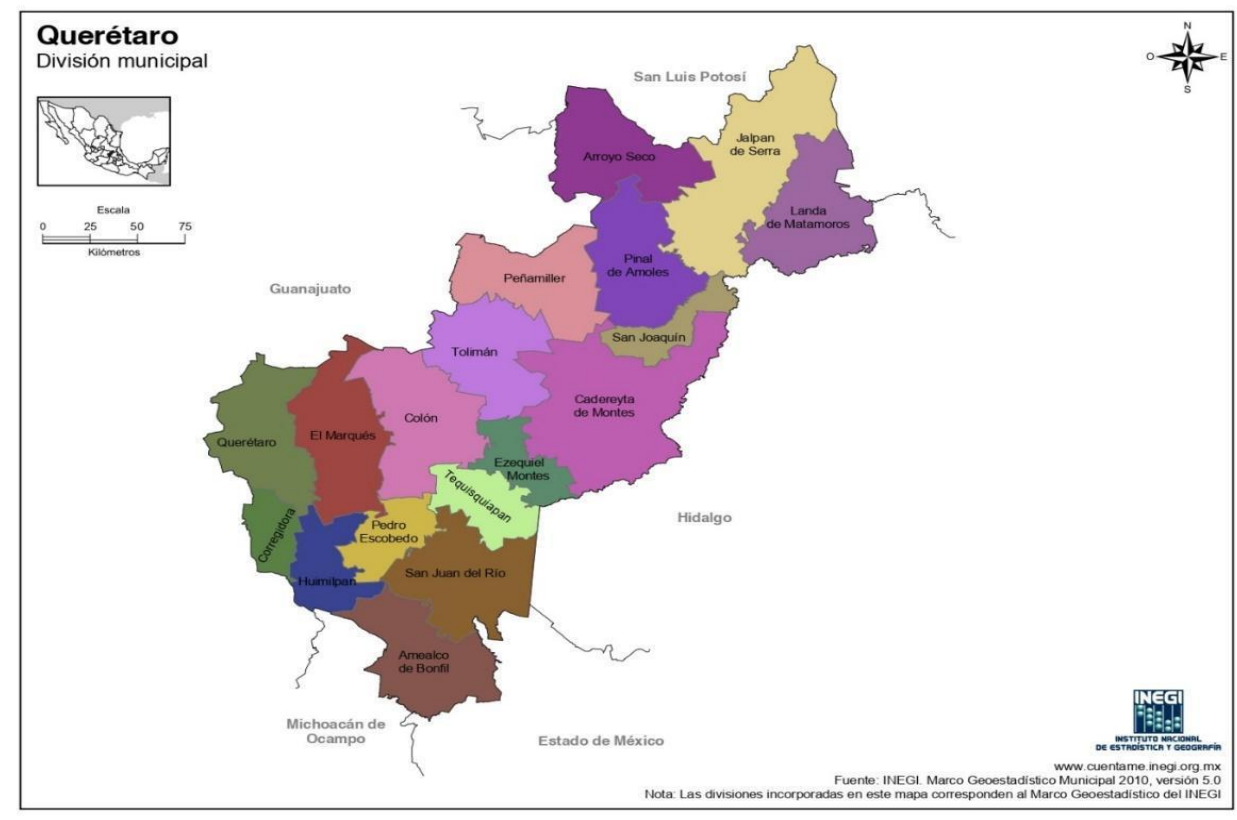

Figure 1. Querétaro, Division municipal

The municipality has 243 localities, of which 241 are considered rural and the other two urban. According to data from the Municipal Development Plan 2018-2021, it has a total population of 69,549 inhabitants (Presidencia Municipal de Cadereyta de Montes, 2018). In Tzibanzá, there are 372 inhabitants, of which 178 are men and 174 women (INEGI, 2019), distributed in 128 families (Information recovered from the interview with the nurse Elsa Ramírez in 2018). According to the National Council for the Evaluation of Social Development Policy (CONEVAL, 2010), 72.9\% of the municipality's population lives in poverty.

Poverty is understood from the perspective of CEPAL: as a situation of deprivation, economic resources, or living conditions that society considers basic by reference social standards that reflect minimum social rights and public objectives. These norms are expressed in both absolute and relative terms and are variable in time and different national spaces (cited in Velázquez \& Castillo, 2015). Tzibanzá is one of the 95 localities 
with a high level of marginalization at the municipal level (SEDESOL, 2018), which explains, among other things, the arrival of development programs and projects.

\section{From rural development to female autonomy}

This investigation arises from a previous proposal. Universidad Autónoma de Querétaro, México (UAQ) professors were invited to carry out a diagnosis before constructing the new El Anzuelo hotel-spa-restaurant, which had an investment of 64.3 million Mexican pesos and was inaugurated in December 2018. The intervention had the objective of identifying the problems they have faced in the organization of the different projects and possible solutions. Hence, we start from the critical approach of development, considering that it cannot only be understood as economic growth but that the "beneficiaries" must either be protagonists or re-appropriate the proposals in order to achieve their goals.

Rural territorial development is taken as a reference, understood as one that considers the territory as a social construction, beyond space, as a place that creates identity and culture. Processes must be understood from the interaction of those who make everyday life possible. This perspective includes governmental and nongovernmental institutions, producers, private capital, and social leaders, up to the inhabitants who depend on and exploit the natural and social resources that they have to survive on their own (Demattis \& Governa, 2005; Flores, 2007; Giménez, 1996; González Casanova, 2004; Rodríguez, 2015; Sosa, 2012).

One of the development projects is rural tourism. It was first defined as a dynamizing factor of local economies that affects the design and planning of economic, social, and cultural policies. Therefore, tourism is a factor that can detonate development (this is understood as economic growth). Also, tourism is considered one of the contemporary capitalist system's expressions, said tourism-development relationship involves several conflicts ranging from access, use of resources, and distribution of benefits (López \& Palomino, 2015).

Rural tourism is a term that was coined in the mid-90s. In opposition to conventional or traditional beach tourism, rural tourism arises in the face of new consumption demands and tourists' leisure needs from the middle and upper classes of highly industrialized urban areas. In Mexico, it has been defined as: "the trips that have the purpose of carrying out activities of coexistence and interaction with a rural community, in all those daily social, cultural and productive expressions of it" (Guevara, 2019). It includes agro-tourism and all types of sports, cultural, gastronomic activities, among others that occur in rural areas and depend on each region's natural, geographic, and ethnological characteristics (Serrano \& Molina, 2002). In Tzibanzá, this activity began together with the Zimapán dam's inauguration. It sought to promote the natural landscape and fishing activities - such as sport fishing - generating new employment and income opportunities for the community in general and the cooperative members in particular.

This work aims not to delve into the dam's construction, since it has already been reviewed in previous articles: Guevara, Rivera, and Hernández (2018), Guevara, 2019ª Guevara 2019b. So, I will only mention that its construction is included in the megaprojects proposal that seeks to detonate the economy and/or provide services -in this case, electricity- to a larger population than the one affected. It is within the limits of Querétaro and Hidalgo's states and was built between 1980 and 1990. However, it was inaugurated in 1995, and this is the watershed of development programs and projects that reach the community. 
Further on, women have been included in development processes since the term gender was included in international social policy. The concept is understood as the cultural construction of sexual difference, that is, being a woman or a man, and it is not a trait that derives directly from belonging to one sex or the other. It is a category to analyze how sexual differences are defined, represented, and symbolized in a given group, which grants characteristics, behaviors, and beliefs about femininity and masculinity. Therefore, women and men's duty is found at a certain time and space and varies between different cultures (García, 2007; Lamas, 2002; Lagarde, 2000).

Gender relationships allow the creation of roles. The roles are a way of living the social rules and behaviors as if they were natural ones. Their function responds to interaction, and they portray ways of being, acting, and feeling that a given social group confers on its members and how those are assumed and expressed in everyday life. They are also reflected in collective and subjective expectations and demands that are assigned based on different criteria such as age, gender, social class, etc. Gender roles are the norms and prescriptions from which tasks and responsibilities are assigned; those are part of a historical and socio-cultural context on female and male behavior. They are socially accepted and generate prohibitions and expectations among the individuals that make up the group. They can vary according to culture, social class, ethnic group, and even people's generational stratum. They are delimited according to the set of responsibilities and obligations of women and men, limiting the performance of both. These can be of the productive type (activities developed in the public sphere generating income, recognition, power, authority, and status), reproductive (activities related to life care) and community (participation in the community to ensure family reproduction) (García, 2007; Lamas, 2002; Murguialday, 2000; Sáenz, 2011).

For this reason, participation in development programs and projects, particularly commercial and sport fishing and decision-making, is considered as an element that modifies gender roles and at the same time enables the construction of female autonomy.

Autonomy is part of the power relationships that are built from gender roles, it does not exist fully because it is in constant construction (Lagarde (2013). It refers to women's ability to carry out a certain activity without requiring the consent of their husbands or some other family member, which means having the capacity and specific conditions to freely make decisions that affect their lives (Casique, 2004). The following types of autonomy can be identified: a) economic autonomy, linked to the possibility of controlling assets and resources; b) physical autonomy, referring to the ability to freely decide on sexuality, reproduction and the right to live a life free of violence and; c) autonomy in decision-making, which implies full participation in decisions that affect the lives of women, their families, their communities and society in general (CEPAL, 2016).

Autonomy it's a social pact that needs recognition and social support. It is built both in vital social processes and in economic ones, in political ones, and it is also a process with a sexual and psychological foundation. To understand this, it is necessary to analyze the entire set of normative aspects of life: legal and non-legal norms and processes (customary) that regulate life and determine gender roles (Guevara, 2019).

It has been said that autonomy, in the case of Tzibanzá, is built from participation understood as communitarian and implies doing, possessing, transforming, and being in movement, going from the collective to the individual and vice versa. It is a consciously assumed voluntary process, which occurs from multiple social constructions. It is subject to contextual values and circumstances that arise at a certain moment in the place where it is carried out. It acquires a systematic development in time and space. It has the group's organization as its fundamental tool, and it must be freely and inclusive (Contreras, 2000, 
Montero, 2004). It enables the achievement of shared objectives that have their origin in group membership. Since it arises from the ability to possess common attributes or qualities, to participate is to share, a condition of being related to a larger whole and consequently feeling included in order to be able to take an equitable part of something. It involves both social awareness of its importance and the individual commitment of people (Gil et al., 2008; Tamayo, 2002).

It enables the ability to decide on certain changes, which may reach increasing autonomy levels; that is, participation is intricately linked to power. It implies achieving independence concerning resource management and decision-making that are the group's responsibility, which can differentially affect the individuals that compose them (Contreras, 2000).

For this reason, I consider women's participation in development processes as a trigger for autonomy since it implies being part of the economic-productive activities that had been considered "masculine" and gives them the ability to decide about their future and that of their community.

\section{METHODS}

I share the idea that reality can only be knowable if the researcher coexists with it; that is why the proposal is made from a qualitative perspective, which allows us to approach phenomena from the perception of those who live them (Corbetta, 2007; Lerner, 1999).

This research was looking to answer the question: is the participation of women in the cooperative activities a detonator for female autonomy? If so, what kind of participation is more important? And why? The research period was from October 2018 to June 2020; we combined a specialized bibliography review with fieldwork.

Initial fieldwork was designed to accomplish rapport with the community, particularly with the women, so we visited the community more than 45 times on different days. We participated in different activities, in meetings and fishing contests, for instance, where the cooperative members make decisions and work together. We combined participatory and non-participatory observation and informal interviews, and we stayed for a couple of days on four different occasions.

Once we got to know people and they recognized us, the questionnaires were created. The objective of those was to gather quantitative information about gender roles, participation, and autonomy. The questionnaires focused on the topics we considered to be the most important: gender roles in the community and the perception of freedom in the decision-making process at home and cooperative affairs. To compare and find out whether the cooperative allows them to build autonomy, we design questionnaires for women who don't belong to the cooperative. In this case, the questions focused on whether they perceived differences between themselves and the cooperative women, and if they participated in community activities themselves, which ones, and if those are exclusively for women and why. We selected this particular community because, in a previous intervention, we wondered if this could be an example of the positive impact that development projects can have on people, particularly for women when they've decided actively to participate in them.

Questionnaires were applied to 20 cooperative women and 32 non-cooperative women (the original intention was to apply them to all 29 women who participated in the cooperative, for reasons beyond the proposal, only 20 were achieved). The selection of non-cooperative members was made based on those women who wanted to participate. The questionnaires included three topics: a) gender roles and patterns, with closed 
questions using multiple choice; b) activities carried out in the cooperative, particularly decision-making, to determine whether or not there is a differentiation between what women and men can or cannot do, with closed and open questions; and c) a Likert scale to measure attitudes regarding autonomy, which sought to identify whether women perceive that they have more or less decision-making capacity regarding their individual, economic, family and community life based on their participation in cooperative activities.

Questionnaires were modified for the non-cooperative women. The difference was to ask them about community affairs and if they perceived a difference between those who are part of the cooperative and themselves. Data were analyzed to determine the percentage of women who consider those activities at home. They are divided by gender, who is making the decisions at home, and the difference between those who participated in the cooperative and those who did not. We wanted to know through the Likert scale, whether they like independent women or not and how they perceive women's economic participation.

An interview script was prepared to emphasize women's feelings, specifically, if they perceived that participating in the cooperative modified the possibility of making individual, economic, family, and community decisions. Two interviews were held with two women who participated in the cooperative. Due to the difficulties involved in agreeing on schedules, the decision was made to apply a focus group in which six women participated, also cooperative members. That information was analyzed using speech analysis. We were looking for the perception of women about their freedom once they started working as commercial fisherwomen.

For this paper, the analysis has been compiled from these questionnaires, interviews, and preliminary conclusions from the focus group.

\section{RESULTS AND DISCUSSION}

The participation of women in Tzibanzá began in 1995 with the Zimapán hydroelectric plant's inauguration and the arrival of the "Women in Solidarity" program. That had the objective of incorporating women in the fight against poverty based on their inclusion in a proposal for infrastructure changes, housing relocation, and productive reconversion to improve their living conditions, feeding, and sometimes generate employment. It was a starting point, as it included the construction of houses that had been relocated with the dam's flooding, the clearing of the land, and the construction of an irrigation system for tomatoes and Zucchini's commercial production. Although only 20 women and their families indeed participated, its impact on their daily lives, particularly on the way women were perceived, was enormous.

Thus, for example, Mrs. Toña and her husband remember how: we all participated ... even though it was for women, we all worked equally ... in what we could, but no house was built alone, everyone also did the clearing of the land and Irrigation since they only gave us the materials (2019). They also remember how irrigation agriculture allowed them to have enough products to sell wholesale. The participation of women positioned them as protagonists of change, with the possibility of leaving their home and doing other activities. It does not mean that gender role will change towards equality. In the questionnaires, we find that for all women, both cooperative and non-cooperative, the main activity continues to be their home, which includes domestic and caregiving tasks. However, they consider that these types of activities have become "simpler" for those who are part of the cooperative since they carry out household chores when they have no other commitments; at least they stated this in the focus group (see graphic 1 and 2) 


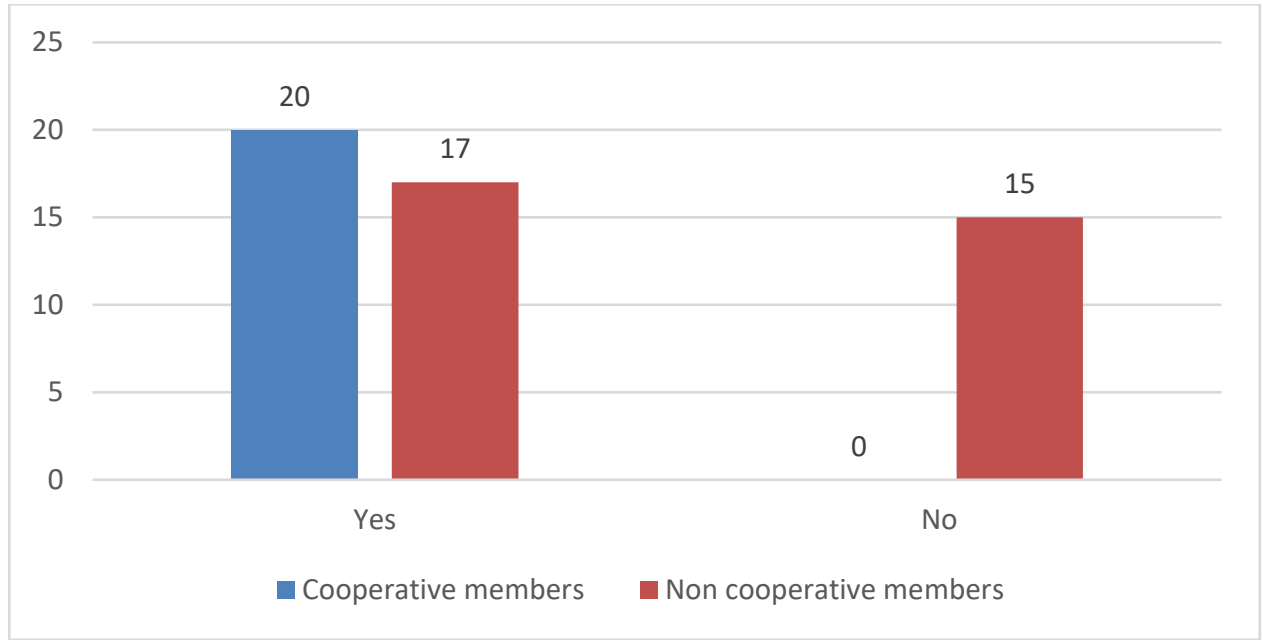

Figure 2. Women who have paid work outside their homes Source: Own elaboration based on the questionnaires raised during 2019.

On the other hand, irrigation agriculture gave them an economic income that made it possible to pay for work in the fields and to have the possibility for new generations to continue studying. The cooperative also arises because of the dam's construction, which, by flooding most of the farmland, leads the inhabitants of Tzibanzá to commercial fishing, initially without permission. Fines and the problems caused by this activity with the authorities led them to explore the possibility of establishing a production cooperative.

The cooperative's formalization was a job that required organization and community participation since it involved hours of work, financial contributions, and other unpaid activities. However, by 2000, 93 cooperative members were already consolidated, including 29 women who work from 4 different committees coordinating each of the activities: commercial fishing, restaurant, hotel El Anzuelo, and La Isla. Even though the committees' functions were unpaid for almost a decade, they have 40 formal jobs in the different areas today.

The income received from the different tourist activities is distributed among all members by equal parts. As for commercial fishing, it is an activity that is carried out independently. Each one of the 93 cooperative members has their permission and their boat, and what they fish is collected by the cooperative, and they have a wholesaler who periodically goes to the town and buys the fish. Each one receives a payment per kilo, at an approximate price of 30 pesos per kilo in 2019.

Although there was no restriction to be a cooperative member based on gender, most of the women entered in the absence of their husbands who were migrants or inherited permission from someone who no longer lives in the community. However, they recognize that when participating, nobody makes them less ... we learned to fish by looking, a brother taught some of us, if not a son or a husband. In addition to that, for them going out to fish represents that: I get to relax, I like it because I get distracted, we are our boss, and we can earn our own money. Women having their income has made it possible for them to decide how resources are used at home, deciding what to do with the money they earn makes them feel freer than their mothers were (GFC, 2019).

Both cooperatives and non-cooperative perceive themselves with greater autonomy, which they find in the possibility of working and receiving an income, decision-making at home, and the possibility of doing other activities outside their house. 
On the Likert scale, we can see it, where totally agree indicates a negative attitude towards autonomy -decision-making- and totally disagree with a positive attitude. We can see a difference between cooperative members and non-cooperative members (Figure 3 and 4). (horizontal axis numeric code: 1). Women don't suppose to work outside their homes; 2). Women have to ask their husbands' permission for any activities they want to do; 3). Women who work are more irresponsible with their homes than women who do not work; 4). When a women work, she is free to decide what happens with the money she earns; 5). Women can be independent when they have their own money; 6). Man prefers women who don't work to be their wives.)

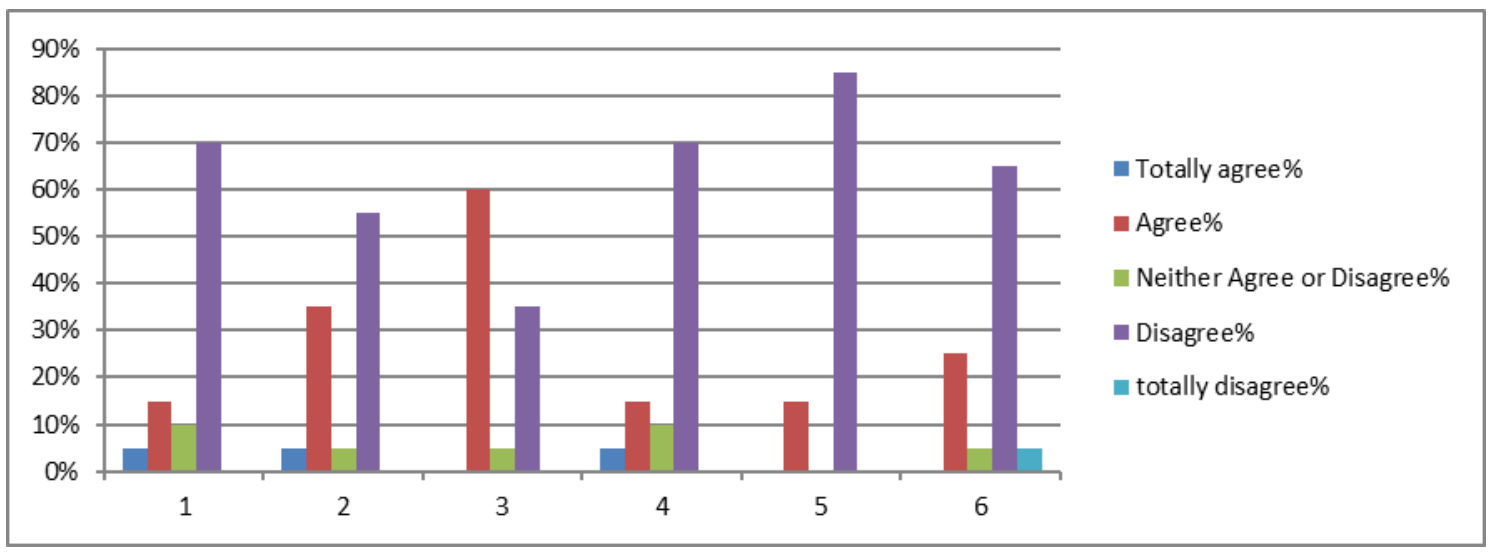

Figure 3. Women's attitudes regarding autonomy (cooperative members) Source: Own elaboration based on the questionnaires raised during 2019

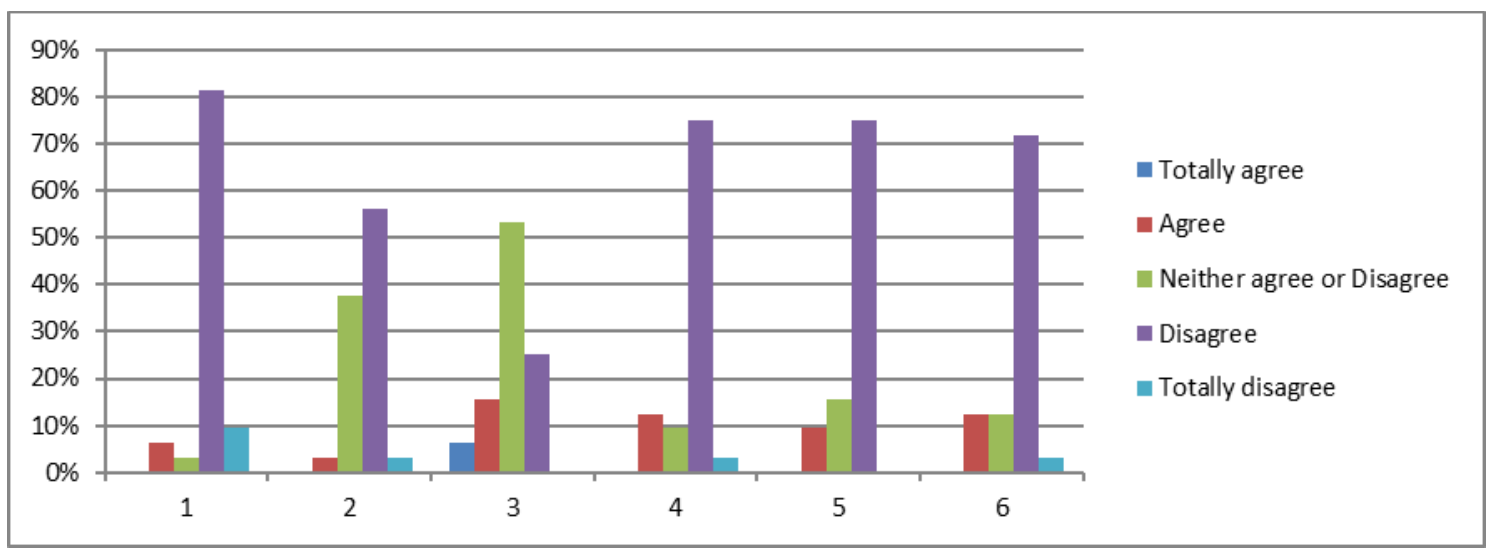

Figure 4. Women's attitudes regarding autonomy (non-cooperative members) Source: Own elaboration based on the questionnaires raised during 2019

When they disagree, give us an indication of how they feel about work, earning money, and making their own decisions at home and in the community. Even though the difference is not big, it gives an idea of how women feel about themselves and others when participating in economic activities and decision-making processes.

\section{CONCLUSION AND RECOMMENDATION}

Female autonomy is a social capacity that women can gain through different activities, in Tzibanzá, for example participating in commercial fishing and the cooperative project. Moreover, autonomy is a process that needed the active participation of women. It's important to recognize the gender roles women have been carrying for 
generations as mothers and caregivers. In the awareness of gender roles, they can move forward to changes. Walking towards female autonomy does not mean either that they stop taking care of their houses and families, but gives them the possibility of doing that not as an obligation but as another activity that can be combined with commercial fishing and other cooperative responsibilities. Therefore, it is possible to say that participating in decision-making on an equal basis with men in the cooperative is a trigger that can lead to the construction of autonomy because this allows them to be perceived with the same opportunities as men.

It is also a social recognition since men are aware that programs and projects would not be possible without women's participation. Those who are not cooperative members find the opportunity to obtain a paid job in the tourist activities that are created, small businesses, cleaning in the new buildings that are rented to visitors, or in other spaces outside the community. In other words, access to economic income has allowed them to feel the independence that enables them to make decisions in every aspect of their personal lives.

There are still questions to be answered regarding what the development proposals represent in the change in gender relationships. However, I can confirm that when the "beneficiaries" appropriate the proposal, economic income is not the most important thing, but, rather, the possibility of deciding on the direction their lives will take. At least in the case of the Tzibanzá's women, which becomes a trigger that enables autonomy construction.

\section{REFERENCES}

Casique, I. (2004). Poder de decisión y autonomía de 1as mujer mexicana. Análisis de algunos condicionantes. Vol. V. México: UNAM

CEPAL (2016). Autonomía de las mujeres e igualdad en la agenda de desarrollo sostenible. XIII Conferencia regional sobre la mujer de América Latina y el Caribe. Montevideo October 25-28.

Consejo Nacional de Evaluación de la Política de Desarrollo Social (CONEVAL) (2010) Recovered from: https://www.coneval.org.mx/coordinacion/entidades/Documents/ Queretaro/principal/22triptico.pdf

Contreras, R. (2000). Empoderamiento campesino y desarrollo local. In: Revista Austral de Ciencias Sociales. N. 4, pp. 55-68

Cooperativity Focus Group (2019, October). Prepared by Ilithya Guevara

Dematteis, G., and Governa, F. (2005). Territorio y territorialidad en el desarrollo local. La contribución del modelo SLOT. AGE Bulletin, 39, Pp. 31-58

Flores, M. (2007). La identidad cultural del territorio como base de una estrategia de desarrollo sostenible. In: Revista Opera, pp. 35-54, (7).

García, M. (2007). ABC de género en la administración pública. Instituto Nacional de las Mujeres/Programa de las Naciones Unidas para el Desarrollo, México.

García, A. (2003) Las contradicciones del desarrollo. El impacto social de los reacomodos involuntarios por proyectos de desarrollo. Mexico: Universidad Autónoma de Querétaro.

Gil Lacruz, M., Izquierdo, A. and Martín, P. (2008). La participación de las mujeres en el desarrollo rural y el bienestar social. Persona, (11), pp. 129-142. Available at: https://www.redalyc.org/articulo.oa?id=147117608008

Giménez, G. (1996). Territorio y cultura, en Estudios sobre culturas contemporáneas,

Epoch II, Vol. II, no. 4, Universidad de Colima; Colima, México; pp. 165-173. 
González-Casanova, P. (2004). Comunidad: la dialéctica del espacio, en Revista Temas N. 36, enero- marzo. La Habana, Cuba, Pp. 4-15

Guevara, I. (2019) Turismo rural. Construyendo autonomía femenina desde la participación. Ponencia presentada en el XII Congreso Nacional, Vivir, sobrevivir y resistir en el campo mexicano. AMER

INEGI, (2018). Instituto Nacional de Estadística y Geografía (INEGI). Inegi.org.mx. Accessed November 30, 2018: http://www.inegi.org.mx/inegi/

Lagarde, M. (2013). Claves feministas para el poderío y la autonomía de las mujeres. Memorias. Puntos de encuentro, Managua. Available at: 2016http: //www.caladona.org/grups/uploads/2013/04/claves-feministaspara-el-poderio-yautonomia_mlagarde.pdf

Lamas, M. (2002). La antropología feminista y la categoría género, en Cuerpo, Diferencia Sexual y Género, Taurus, México

Montero, M. (2004). Introducción a la psicología comunitaria: desarrollo conceptos y procesos. Argentina, Paidós.

Murguielday, C. (2000). Roles de género. In: Diccionario de Acción Humanitaria y Cooperación al Desarrollo, recuperado en: http://www.dicc.hegoa.ehu.es/listar/ mostrar/115

Presidencia Municipal de Cadereyta de Montes (2018). Plan Municipal de Desarrollo 2018-2021.

Rodríguez W., C. (2015). Capítulo 1. Geopolítica local: territorialidad y desarrollo. In: Geopolítica del desarrollo local. Campesinos, empresas y gobiernos en la disputa por lo territorios y bienes naturales en el México rural, pp. 23-38. Mexico, UAM$\mathrm{X}, \mathrm{ITACA}$

Sáenz, A. (2011). Una mirada a la racionalidad patriarcal en México en los años cincuenta y sesenta del siglo XX. México, Universidad Michoacana de San Nicolás de Hidalgo-Plaza y Valdés.

Serrano, LM, and Molina, AV (2002). Análisis del concepto de turismo rural e implicaciones de marketing. In: Boletín económico de Ice, 2002, pp. 25-36

Sosa, M. (2012) ¿Cómo entender al territorio? Universidad Rafael Landívar, $1^{\text {a }}$ Edición, Guatemala

Tamayo, S. (2002). Ciudadanía e identidades urbanas, ponencia presentada en el VI Encuentro de Cultura y Ciudades Contemporáneas, CIESAS, ITESO, Universidad de Guadalajara.

Toña (2019, January). Personal Interview.

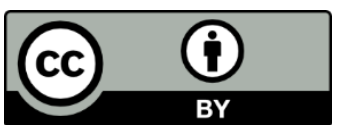

(C) 2020 by the authors. Licensee JPPD, Indonesia. This article is an open-access article distributed under the terms and conditions of the Creative Commons Attribution (CC BY) license (http://creativecommons.org/licenses/by/4.0/). 